\title{
The affective life of semiotics
}

\author{
J. S. Hutta \\ Department of Geosciences, Bayreuth University, Bayreuth, Germany \\ Correspondence to: J. S. Hutta (hutta@gmx.net)
}

Received: 2 December 2014 - Revised: 9 July 2015 - Accepted: 2 September 2015 - Published: 14 October 2015

\begin{abstract}
The paper challenges writings on affect that locate affective dynamism in autonomic bodily responses while positing discourse and language as "capturing" affect. To move beyond such "verticalism", the paper seeks to further an understanding of language, and semiotics more broadly, as itself affective. Drawing on participatory research conducted in Rio de Janeiro, it uses poetic expression as a paradigmatic case of the affective life of semiotics. Conceptually, it builds on Guattari's discussion of affect in connection to Hjelmslev's semiotic approach and Bakhtin's account of the process of enunciation. It is argued that semiotics play a crucial role in conjuring affective intensities, whereby expressions themselves become affective, as they modify sensory and material registers including prosody and the voice. The argument thus leads to a new understanding of the expression of affect as well as the affectivity of expressions. As expressions become affective, they draw subjects into ongoing processes of affecting and being affected. Such a view moves away from conceptions of semiotics "capturing" or even "translating" or "constructing" affect. It also displaces prevalent conceptions of "affective transmission" in terms of the circulation of physical substances body to body. Moreover, it furthers discursive and semiotic methodologies while also inviting a reconsideration of affective ontologies.
\end{abstract}

An affect speaks to me, or at the very least it speaks through me.

\section{F. Guattari (1996:160)}

\section{Introduction: when affect speaks}

When in the mid-2000s contestations around the uses and abuses of "affect" and the so-called "non-representational theories" came to the boil, the question of language played a pivotal role. Non-representational theorists of affect have tended to view language as affect's representational other. Eric Shouse, for instance, asserts that "affect cannot be fully realised in language" (2005:5). And Nigel Thrift, in his influential paper Intensities of Feeling, quotes Katz to suggest that when emotions occur in speech, "they are ways of expressing something going on that talk cannot grasp" (Katz, 1999:4, quoted in Thrift, 2004:60). Positing processes of affecting and being affected to be at the heart of the world's ongoing genesis, these authors glimpse conceptual and methodological innovation in an appreciation of bodies' unforeseen affective capacities (regarding the discussion in Anglophone geography see Anderson and Harrison, 2010; Lorimer, 2005, 2007, 2008). Body and environment are viewed here not merely as passive screens to be inscribed and moulded by discourse (see Massumi, 2002a; Thrift and Dewsbury, 2000), a view pervasive especially in the Cultural Studies debates of the 1990s. ${ }^{1}$ Rather, taking bodily capacities for worldmaking seriously seems to promise a new understanding of embodied agency and materiality as well as of thought and intelligence (see for instance Connolly, 2002; Thrift and Dewsbury, 2002; Seigworth and Gregg, 2010; Massumi, 2002a; Manning and Massumi, 2014).

In the same breath, however, non-representational understandings of affect have tended to ground themselves on a reductive understanding of language - on a "representationalist view of representational practices", as Barnett puts it (2008:189). In fact, a special appeal seems to have resided in affect's generic rejection: "not semiosis, not meaning, not structure, not apparatus" (Brinkema, 2014:xii, emphasis in

\footnotetext{
${ }^{1}$ Brinkema notes, "The turn to affect, thus, is part of a larger reawakening of interest in problematics of embodiment and materiality in the wake of twentieth-century Western theory that, for many, was all semiotics and no sense, all structure and no stuff' (2014:xi).
} 
the orig.). Wetherell even diagnoses a "rubbishing of discourse" (2012:19), as discourse is often framed as that which arrests or "captures" affective dynamism. In response, critics have challenged the search for direct, pre-semiotic affects, and questioned the autonomous status accorded to neurological and visceral processes (see Korf, 2012; Leys, 2011; Mazzarella, 2009; Papoulias and Callard, 2010). Feminist authors in particular have lamented the dismissal of cultural meanings, lived experience and reflexive thought (see Bondi, 2005; Hemmings, 2012; Sharp, 2009; Thien, 2005). Instead, critics have commended various approaches including analytical philosophy, psychoanalysis, practice theories, phenomenology and feminist emotional geography to gain a more complex understanding of the mutual imbrication of language and affect or the emotions (e.g. Ahmed, 2014; Barnett, 2008; Bondi, 2005; Gould, 2009; Wetherell, 2012).

As affect theorists have often set all-too-clear boundaries against discourse, critics have however tended to caricature the increasingly diverse range of writings on affect. They have thereby tended to foreclose engagements with what might still be productive in thinking with affect. In fact, authors like Thrift $(1996,2000)$ or McCormack (2003:502) have themselves long called for viewing representations as performative and processual practices. ${ }^{2}$ In addition, recent publications display a lively interest in the role of linguistic features like commentary, narrative, everyday speech, writing, silence, rhythm or the voice within affective and morethan-representational scenarios (see Bissell, 2015; Dewsbury, 2014; Kanngieser, 2011; Kleres, 2011; Laurier, 2010; McCormack, 2013). David Bissell (2015), for instance has explicitly situated his analysis within the renewed interest in geographies of speech (see Brickell, 2013). And Brian Massumi, who has been attributed a central role in the "rubbishing of discourse", has offered refined elaborations on language's relations to other levels of experience (Massumi, 2012).

Interestingly, then, contestations around affect and the non-representational have at the same time reinvigorated discussions around language, discourse and meaningmaking. Interpellating both proponents and critics of nonrepresentational approaches, these discussions also link - implicitly or explicitly - to engagements with language and affect in anthropology and the philosophy of language (e.g. Besnier, 1990; Cavell, 2005; Konstantinidou, 1997; Riley, 2005). As the quarrel around affect's non-representational alterity to language is becoming increasingly tired, attention is shifting to how language and affect are mutually implicated. The issue is intricate, though. Wetherell has listed a range of verbs used to qualify the relation between discourse and affect, including "taming", "codifying", "completing", "translating", "representing", "expressing" and "construct-

\footnotetext{
${ }^{2}$ See also Crouch (2001), Latham (2003) as well as Thrift's $(1996,2000)$ discussions of John Shotter's dialogic approach to language and conversation.
}

ing" (2012:52). The variety of routes into the "deeply murky territory" (p. 51) of affective-discursive or affective-semiotic relations can be perplexing. Mapping out various facets of these relations from different theoretical angles, as Besnier or Wetherell do, is useful to complicate simplistic binaries. The following section contributes to such mappings by discussing some recurrent themes in non-representational approaches. To move towards a more consistent understanding of the affective life of semiotics, however, the paper then elaborates on what I see as some critical points of affectivesemiotic relations. In particular, it engages the twin problems of the expression of affect and the affectivity of expressions - the becoming-expressive of affect and the simultaneous becoming-affective of expression.

\section{Non-representational approaches and the vertical trap}

Non-representational approaches to the relations between affect and semiotics have raised a number of issues that might assist in refining our conceptual understanding of these relations. They have at the same time circulated around a verticalist model that is in need of further interrogation. Most pervasively, affective dynamics are seen as disposing the body to perform certain actions, including speech. Seigworth and Gregg thus note, "Affect is the name we give to forces visceral forces beneath, alongside, or generally other than conscious knowing, vital forces insisting beyond emotion that can serve to drive us toward movement, toward thought and extension [...]" (2010:1, emphasis in the original). In this view, affects can propel one to speak (or to be silent), which can be "felt" as "the registering of an intensity", as "a sense that some kind of difference is in the making" (McCormack, 2013:33). ${ }^{3}$ Affective dynamics are seen here as animating as well as "conditioning" language and discourse (Anderson, 2014).

Directing attention towards how affective tendencies immanent to bodily and material configurations both animate and condition discourse raises vital issues for discursive methodologies and for investigations of social and material life more broadly. In particular, it seeks to address the powerful, non-discursive forces at work when we communicate. This could be related, for instance, to Michel Foucault's emphasis on the irreducible dependence of discursive formations on extra-discursive elements (Wrana and Langer, 2007), as well as to his work on power (see Deleuze, 1999; Schregel, 2012). These affective tendencies, however, are then often framed in problematic terms, locating affective dynamism on non-conscious bodily strata frequently summarised under the rather elusive rubric of the "visceral" -

\footnotetext{
${ }^{3}$ Thrift makes a similar point when he invokes Vygotsky's argument that " $[\mathrm{t}]$ he affective and volitional tendency stands behind thought" (Thrift, 1996:7; see also Shouse, 2005).
} 
as in Seigworth and Gregg's above-cited formulation. ${ }^{4}$ Assuming viscerality to be at the heart of the force animating and conditioning language and speech also has implications regarding the framing of semiotics.

Brian Massumi's (1995) essay The Autonomy of Affect, republished in his 2002 book Parables for the Virtual, has left a lasting legacy in its account of semiotics as that which captures affect. ${ }^{5}$ The book as a whole develops a passionate argument in favour of the primacy of the visceral, commenting on semiotics only in passing. For Massumi, viscerality is key to the generation of autonomic affects, considered as profoundly shaping subjectivity and even politics (see in particular pp. 57-65). He understands viscerality as a particular mode of perception that registers excitations gathered by the senses "before they are fully processed by the brain" (p. 60). As an example, he notes, "Walking down a dark street at night in a dangerous part of town, your lungs throw a spasm before you consciously see and can recognize as human the shadow thrown across your path" (ibid.). Viscerality is conceived here as the perception of a kind of suspense, characterized by a temporary "inability to act or reflect, a spasmodic passivity" devoid of any "quality". Instead, it is marked by degrees of "intensity", which characterise affect in its "ability to affect and [...] susceptibility to be affected" (p. 61).

This conception has inspired numerous authors to trace the efficacy of affective dynamics unfolding below thresholds of conscious reflection. In the same stroke, however, Massumi relegates semiotics to the role of arresting affective dynamism: "The emphasis is on process before signification or coding. The latter are not false or unreal. They are truly, really stop-operations" (p. 7). Meaningful elements come into play here only after an event has already been dynamically processed by the senses. They are said to code or qualify affective intensity by "linearizing" it through "semantically and semiotically formed progressions" (p. 28). The "virtual" dynamism of affect is thus "captured" at the moment of its "actualisation". ${ }^{6}$ Massumi has famously reserved the term

\footnotetext{
${ }^{4}$ Papoulias and Callard summarise, "The turn to affect is thereby a turn to that 'non-reflective' bodily space before thought, cognition and representation - a space of visceral processing" (2010:34; cf. Leys, 2011:437). In a similar vein, Korf sees this turn as a "neural turn" (2012:146).

${ }^{5}$ Mazzarella calls The Autonomy of Affect "perhaps the most significant recent scholarly intervention" (2009:292) in the discussion of affect (see also Wetherell, 2012:56). In Anglophone geography, Massumi's prominence is evident from its central role in influential texts like McCormack (2003), Thrift (2004) and a range of further publications.

${ }^{6}$ As Constantin Boundas (2005) notes, the idea of the "virtual" and its relation to the "actual" goes back to medieval philosophy and has been mobilised especially by Henri Bergson, and later by Deleuze in his engagements with Scotus, Bergson, Spinoza and Nietzsche (as well as Foucault, I would add).
}

"emotion" for linguistically captured affects (p. 28). ${ }^{7}$ Where visceral affect is seen as creating intense, virtual "suspense", semiotic coding is viewed as instantiating dull, actual "expectation". I term this conception the "semiotics-as-capture" axiom.

If Massumi still emphasises that it "would be a mistake to equate the reflex with the purely physical", it is because elements of conscious reflection and coded language are also said to be folded back into visceral perception, where they however again constrain the body, this time already on a visceral level (2002:75, see also pp. 29-30). All of the body's visceral excess that transpires to the level of thought is "sensation", meaning a vague "registering of potential" (p. 97). The "layers" of what Pile terms a "layer-cake model" of subjectivity remain thus largely separate.

Semiotics-as-capture has been the axiom undergirding non-representational accounts of the relation between affective tendencies and semiotic expression. Some accounts, however, also highlight the dynamism inherent in expressivity. Such a view is signalled already by Katz' abovecited formulation that when emotions occur in speech, "they are ways of expressing something going on that talk cannot grasp". In a similar vein, scholars like Connolly (2002) have also suggested to view propositional arguments as being inhabited by noise, unstated habit and visceral affective intensities (see Leys, 2011:436). Speech is viewed here as expressing something affective despite of itself, as it were. Bissell's (2015) and McCormack's (2013) engagements with commentary and Massumi's (2012) discussion of digital art veer into a similar direction. These authors are interested in how the rhythm of digital messages "carries the force of the phrase, above and beyond its structure and meaning" (Massumi, 2012:42), or how the speech of commentary is "revealing of [...] the affective, material forces of our environments" (Bissell, 2015:149).

This raises another issue worth further exploration: it shifts from the question of implicit meanings, which is at the heart of hermeneutic approaches, towards a focus on implicit affects. It moreover directs attention to the affectivity of expressions, which is a key concern of this paper. In an essay far less cited than The Autonomy of Affect, Massumi even invokes an "autonomy of expression" (2002a:xxxi). The way in which he and other non-representationalist authors have proceeded in tackling the issue, however, has tended to be consistent with the vertical model. Massumi elaborates, "Certain practices of expression are capable of actualizing the momentum of emergence as such, uncaptured. This is expression in its free state, under formation, tortured but unbound (tortured and for that very reason unbound)" (p. xxiii). Language itself is thus able to gain an "intensity and virtuality" (ibid.). This view is consistent with Massumi's account in The Autonomy of Affect, where he seeks to recuperate the

\footnotetext{
${ }^{7}$ For critical discussions see Korf (2012), Leys (2011), Mazzarella (2009), Wetherell (2012).
} 
"expression-event" (2002:26) at work in language by positing "two entirely different orders" (ibid.) of language: one eventful, the other semiotic. While the invocation of eventful language seems to soften the barrier between visceral and semiotic levels, this eventful functioning of language is in fact restricted to some "tortured" liminal state where articulation is a mere "cry of expression" (Massumi, 2002b:xxiii). ${ }^{8}$ The other, static order of language is meanwhile equated with "the semantic or semiotic level, however that level is defined" (Massumi, 2002a:26-27).

Again, affect's dynamism proper thus originates on the visceral strata of sensation, from where it ripples out towards the level of expression. In such a framework, linguistic expression can at best "amplify" the primary visceral intensities "at the price of making itself functionally redundant" (p. 26). In fact, the view that speech "amplifies" - or, conversely, dampens - visceral affect pervades non-representational writings. ${ }^{9}$ In a similar vein, but perhaps more interestingly, several authors also invoke Massumi's (2002a:76) notion of affective "modulation" (e.g. Anderson, 2014; Bissell, 2015; McCormack, 2013). Derek McCormack moreover draws on Michel Serres to frame commentating as "semiconducting the materialist energies of moving bodies" (2013:14). If affects are "intense", which I do not contest, it might seem consequential to consider the amplification, dampening and modulation of such intensity. Such notions again direct attention to affective forces, as Ben Anderson highlights when, striving for a "technique of affective modulation" (2006:749-59), he makes the "Spinozist point that an affect can be changed only through the energetic creation of another affect" (p. 738). ${ }^{10}$ Yet, the question still remains just where affective intensities are generated and how they are modulated. Attributing affective genesis to neurological levels of viscerality and viewing language and semiotics as secondary modulating devices does not escape the vertical trap. While engagements with the environment decentre viscerality, they still tend to view semiotics as capture. Either way, semiotic expression is granted no affective capacity of its own, except where visceral or environmental forces push it towards its limits. Hence, these approaches fail to account for semiotics' constitutive, rather than derivative, role in affective processes.

Finally, some authors have been interested in the reverse movement, from language to the visceral. Anderson (2014) thus invokes Hochschild's and Lupton's concepts of "feeling

\footnotetext{
${ }^{8}$ Massumi uses the example of a lightning perceived by the body and subsequently inspiring all sorts of cultural expressions. His engagement with autistic language, together with Erin Manning (Manning and Massumi, 2014), goes into a similar direction.

${ }^{9}$ Bissell for instance, discussing the affective dynamics of commentary, is concerned "with how commentary serves to amplify or dampen particular affects" (2015:152).

${ }^{10}$ With Guattari (1996:159; Guattari and Rolnik, 2008:403-5) I however would contest the actually non-Spinozian move of equating affective intensity with "energy".
}

rules" and "emotional discourses" to appreciate the "mediating" role significations play in what he calls the "conditioning" of affective life. He thus seeks to extend the analysis towards discussions of "structures of feeling" in the wake of Raymond Williams or bodily "habitus" following Pierre Bourdieu (see also Gould, 2009). Affect, then, not only drives discourse, but discourse also conditions affect. This notion of mediation seems to complicate the search for autonomic affective excess, further softening the barriers between visceral and semiotic "layers": how "autonomic" are affects that are conditioned by discourse? However, Anderson's view leaves the semiotics-as-capture axiom intact, as semiotics is once more that which constrains and conditions affect. In fact, considering such reverse processes mirrors Massumi's above-mentioned assertion that elements of conscious reflection and language can be folded back into visceral perception. Responding to an "inside out" model with an "outside in" model only takes us so far, as Ahmed (2014:8-11) has rightly observed.

Non-representational approaches, then, have raised important issues around affective tendencies and the becomingaffective of expressions, but they have persistently conflated the site of affective dynamism with that of the visceral body, gravitating around a vertical model. Variants of this model range from "layer-cake" types, where visceral and the semiotic are posited as strictly separate, to those that include moments of mediation, rippling-through and mutual folding. The point is not that affect does not unfold through bodily and material levels, or that it cannot exceed language; it does and it can! But conceiving of viscerality as the generative site of affect per se and viewing semiotics as secondary mechanism of capture leads to reductive understandings of both body and language.

Non-representational discussions of affective-semiotic relations can still assist in refining our vocabularies for engaging with dynamics of affecting and being affected that are constitutive of subjective, social and material formations. Most promising, perhaps, are approaches that engage with concrete forms of expression like commentary, narrative, the "refrain" or with expressive features like the voice, which I will address later on. Such features should not, however, be viewed as liminal phenomena, as special cases where language partakes in affect despite of semiotics' capturing powers, as in Massumi's discussion of "expression-events". I will instead highlight how features like poetics, evocation, prosody or voice are paradigmatic of the affective life of semiotics.

It is further worth noting that several authors, including Bissell (2015), Crouch (2001), Kanngieser (2011), Laurier (2010), Massumi (2012), McCormack (2013) and Thrift (2000), have also situated their discussions within the field of performative approaches in the wake of Charles Austin, Mikhail Bakhtin or Judith Butler, viewing linguistic representation itself as part of dialogic and non-representational practices. My own approach is indebted to such performa- 
tive and practice-based understandings of language. Viewing language as performative, however, does not per se resolve the questions of how affect is expressed or how expressions affect. It is one thing to assert that utterances are doings, but quite another to account for the affectivity expressed by and unfolding through utterances. ${ }^{11}$ To move towards a more capacious understanding of the expression of affect and the affectivity of expression, let us reconsider the notion of semiotics.

\section{Reinvigorating semiotics, or, sensory and problematic affects}

Affect is about sense as well as sensibility.

\section{Wetherell (2012:13)}

Semiotics is a rich analytic tool for investigating not only discourse, but the whole range of sonic, visual and bodily expressions - including vocal, written, graphic, gestural and potentially even termic, tactile or olfactory ones (Eco, 1984). Apart from designating the study of signs, "semiotics" also refers to particular regimes or systems of signs. Such semiotics are at work in humans and non-humans, in organic life and technology, in infants and world systems, at bodily and mental levels. Apart from different national and regional languages, we can for instance distinguish between the semiotics used by different species, or between expressive formations such as a "semiotic of morality", a "normative" or a "deterritorialised semiotic". "Semiosis" refers to the dynamic, powerful process through which specific systems of signs emerge from all kinds of matters as parts of larger social, biological and technological assemblages. Such a view already complicates binaries of materiality/language and calls for a different conception of the relation between semiotics and affect.

Scholars of the Copenhagen School of linguistics around Louis Hjelmslev have investigated how semiosis "forms" signs through the interdependent planes of "expression", i.e. the sign's concrete material manifestation, and "contents" pertaining for instance to the sign's imaginary or conceptual manifestation (see Hjelmslev, 1961). They have developed an open-ended conception according to which in forming "expression-substances" (e.g. a particular word or gesture) semiotics can use a potentially infinite range of matters. A particular expressive form can thus involve gestures, sounds, images and so on, shaping and constellating these expression-substances into a semiotic as it contingently relates them to particular content-substances. Semiotic con-

\footnotetext{
${ }^{11}$ As Cavell (2005) shows in his discussion of Austin (1962), the perlocutionary effects of speech acts, which include the affectivity of utterances, have received far less scrutiny than the performative (illocutionary) act of "doing something by saying something."
}

tents and expressions are indissoluble in that they exist as such only in their mutual presupposition.

Guattari mobilises this open-ended conception of semiosis as the relational formation of expressions and contents to highlight semiotic heterogeneity and dynamism (for a detailed discussion, see Genosko, 1998). Semiosis, he emphasises, exceeds any necessary submission to linearization or "signifying semiologies" that are based "on the bipolarity signifier-signified" (1996:148). The notion of signification undergirding Lacanian cultural analysis and a range of post-structuralist semiologies is the effect of just a particular type of semiosis unfolding in the midst of "polysemiosis" or "heterogenesis", which has the capacity to foster ever new "eventful compositions" (1996:159). This contrasts with Massumi's postulate of a generic "linearizing" (as well as subjectivating) function of semiosis. ${ }^{12}$

Crucially, Guattari's understanding of polysemiosis troubles the semiotics-as-capture axiom by disrupting the verticalist model, where affective expression is chiefly about visceral sensations that are being "coded", "amplified", "modulated", "translated", etc. Instead, Guattari distinguishes between "sensory" and "problematic" affects. Sensory affects subsist within particular forms of expression, such as the intonation of an actor that "will fix the melodramatic turn of an action" (Guattari, 1996:164). Such affects emerge from material components (expression-substances) conceived by the senses "as being immediately there" (ibid.: 160). This notion of sensory affect speaks to the non-representational interest in material processes of affecting and being affected. At the same time, however, sensory affects are not opposed to semiotics, but rather integral to semiotic dynamism, as will be further elaborated below.

The role of semiotics is even more obvious in the case of problematic affects. Where sensory affects subsist within expressions, problematic affects emerge from the complex contents evoked and shaped by these expressions:

For example, the leitmotifs of the Rheingold will induce in me countless sentimental, mythical, historical, and social references, or, the evocation of some humanitarian problematic will trigger a complex feeling of repulsion, revolt, and compassion (p. 160).

Again, this conception of content-related affect will be fleshed out in more detail later on. What is important here is that affects are conjured through the planes of both expression and contents: through "sensory" forms of expression like an intonation as well as through "problematic" contentsubstances like the references evoked by a musical motif.

\footnotetext{
${ }^{12}$ Keeping an eye on "polysemiosis", we can for instance investigate the proliferation of affective dynamics that ensue as people make their worlds through the naming of places (Tuan, 1991:686). Such an investigation does not need to eclipse processes of homogenisation or normalisation through words and names, which can be at work simultaneously, as we shall see.
} 
Both types of affect are hence generated through semiotic means. What is more, rather than positing the sensory as privileged site of affect, Guattari considers problematic affects to be "at the basis of sensory affects"; they are "affect in its 'rich' version" (1996:161). It is the dynamism conjured through semiotic content-substances that is thus first and foremost generative of affective life in Guattari's view. ${ }^{13}$

Instead of capturing affective dynamism, then, semiotics "induce" or "trigger" affect through the planes of both contents and expression. Such processes can be viewed as the becoming-affective of semiotic signs, or what I call the "affectivity of expression" (where expression presupposes contents, and vice versa). However, rather than performing redundant operations of dampening or amplifying visceral intensities, the affective dynamism at stake can likewise take its lead from all sorts of semiotic contents and expressions, working sideways rather than vertically, as it were. (I will draw attention especially to the affects conjured through the evocation of poetic images.) Such a conception thus displaces the verticalist view of semiotics "taming", "codifying", "translating", or even "dampening" or "amplifying" affect. Instead, affect can be said to "subsist within" contents and expressions, which means that it inheres as virtual force and becomes effective (actual) at the very moment of expressive articulation (or "enactment"). ${ }^{14}$ I term such eventful semiotic actualisation the "expression of affect", and will discuss it later on in relation to the enactment of poetry through recital, writing and listening. As we shall see, the affectivity of expression and the expression of affect are in fact different aspects of the same unfolding affective-semiotic process: affects subsist within expressions, which become affective through articulation.

Thus considering sensory and problematic affects also calls for re-examining emblematic examples of the affect literature, such as Massumi's shadow "impinging" on the nervous system: the apparently "autonomous" affect arguably emerges from the sensory perception only as the expressive form of a powerful semiotic is simultaneously actualised. Or else, what makes "your" lungs throw a spasm when seeing a shadow "in a dangerous part of town", while the lungs of a dog or even another person wandering the same street might stay calm? Is not "your" evaluation of this part of town as "dangerous" already part of a semiotic regime (safe/unsafe, order/disorder)? A problematic affect related to the semiotic

\footnotetext{
${ }^{13}$ Guattari specifies that "an affect which one calls sensory is given as being immediately there, whereas with problematic objects, an affect's spatio-temporal congruence dissolves and its elucidating procedures threaten to fly off in all directions" (1996:16061).

${ }^{14}$ I am deriving the notion of "subsisting" from Deleuze's (1990) discussion of the Stoic "incorporeal entities". These entities, Deleuze points out, "are not things or facts, but events. We cannot say that they exist, but rather that they subsist or inhere (having this minimum of being which is appropriate to that which is not a thing, a nonexisting entity)" (p. 5).
}

contents of "danger", in other words, is folded into (or is "at the basis of") the sensory affect that emerges from the visual percept of the shadow. Far from pre-semiotically impinging on your nerves, the shadow has thus already become an affective semiotic expression.

The issue is even more pronounced in relation to Massumi's (2002a:22-8) infamous invocation of an experiment by German psychologist and media scholar Hertha Sturm, where groups of subjects watching a film with or without different kinds of voice-over showed different autonomic skin reactions. ${ }^{15}$ Massumi posits the images as directly impinging on the nervous system, generating affect, whereas he considers the words participants hear as semiotically coded, capturing or redundantly amplifying visceral affect. Not only does this obscure the semiotic vicissitudes of images, it conversely strips words and voice of their affective dynamism. To account for the different affects that images and (different kinds of) voice-over produce, the distinctive ways in which problematic and sensory dynamics unfold in each case would need to be examined. To flesh out in more detail the affective life of semiotics as it emerges from a double focus on forms of contents and forms of expression, I will now turn to poetic practice.

\section{The poetics of expression}

We should prescribe poetry in the same way that vitamins are prescribed.

\section{F. Guattari (1996:328)}

Poets and writers more broadly have long been aware of, and depended on, the affectivity of language. Black feminists like Audre Lorde, for instance, have deployed the capacity of poetry to reconstitute experience through affectively intense semiosis where prevalent forms of representation have failed them (see also Rinhaug, 2012). Poetic language is affective in the two senses of the expression of affect and the affectivity of expressions. Firstly, constellating meanings, memories and images as well as sounds and rhythms, poetic language conjures and reworks the problematic and sensory affects subsisting within them. This is a process of poetically expressing affect. This process, secondly, renders poetic expression affective, thus impacting on the constitution of experience and subject formation.

While my focus will be on a concrete poem, I situate my approach within a broader understanding of "poetics" as a dimension of expression, rather than as a separate aesthetic realm. ${ }^{16}$ Related to the Greek poiesis, a making or creation,

\footnotetext{
${ }^{15}$ Leys (2011) points out some internal contradictions in Massumi's reading of the experiment.

${ }^{16}$ This understanding resonates with Raymond Williams' (1977) recuperation of poetry as a "function". For related discussions of expressive performance in cultural anthropology see Bauman and
} 
poetics has to do with the generative working of semiotics - for a particular experiential and aesthetic purpose, in the case of poetry (see Perloff and Dworkin, 2009a). It is in this sense that Bakhtin asserts, "poetry needs language in its entirety, in all its facets and all its constituents" (1990:294). ${ }^{17}$ This can include the widest possible range of semantic and syntactic variation, stylistic devices, prosody, dialogism, and various other features pertaining to both semiotic contents and expressions. In its performance, the reciting of poetry also involves the body, including diaphragm, lungs, throat or tongue, and it might be directed to an audience interpellated into the event (see Novak, 2011). We shall see how affects are implicated in such processes.

My research with lesbian, gay, bisexual and trans people in Rio de Janeiro involved participatory workshops, where subjects explored, through maps, video, theatre, discussions, diaries and other methods, their affective relations to the spaces they inhabit in daily life (2010:235-45). A workshop participant, Marcello Taurino, wrote a poem, which will accompany the rest of my discussion. ${ }^{18}$ In the course of the research, apart from other discussions of fear, desire or securitisation, we became particularly interested in the Portuguese concept of aconchego, which also inspired Marcello's poem. While this noun can be approximated through the English term "sense of cosiness", it is also used, more broadly, to designate a sense of comfort and feeling well in a place. Similar to the German Geborgenheit (see J. S. Hutta, 2009, 2010), ${ }^{19}$ aconchego's etymology has spatial resonances, as it derives from the verb aconchegar, meaning "to put or turn close to someone or something", "to embrace", "to wrap or cover oneself/someone/something in", or "to make more comfortable" (Houaiss Dictionary). These spatial resonances make the term particularly suitable for tracing intense feelings of comfort and nested-ness in an immediately spatial sense. In the group workshops, the question of aconchego proved productive, as it placed a focus on exploring where and to what effect affective intensities are at play that allow one to nest within, open up to or stake claims to spaces - and what impedes this. Such explorations modify discussions of home,

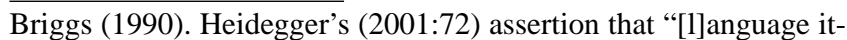
self is poetry in the essential sense" comes to mind as well.

${ }^{17}$ The emphases in the quotes from Bakhtin and Guattari are in the original works.

${ }^{18}$ Marcello Taurino is the participant's social and stage name, which he explicitly wished to have included in my publications. The present section is based on a recording of a workshop session on 29 October 2007 in Rio de Janeiro's Centro district. Translations from Portuguese are mine.

${ }^{19}$ While aconchego and Geborgenheit share semantic similarities, they are no direct equivalents. Dictionaries tend to translate aconchego with other German words like "Behaglichkeit" or "Gemütlichkeit". English dictionaries use "cosiness" or "cuddle" for aconchego, whereas, somewhat misleadingly, they use "security" for Geborgenheit.

belonging, or place in interesting ways, although this can be touched upon here only cursorily.

Below is a slightly abbreviated transcript of the poem $O$ Aconchego coupled with a rather a-poetic translation into English - a translation of the words, rather than the poetic verses. A prominent feature of the poem is its play with aconchego's various grammatical forms, including the verb aconchegar, the participle aconchegando and the adjectives aconchegante and aconchegável. The translation deals with the difficulty to account for these various forms by leaving aconchego and its verb forms intact and adding English equivalent endings, such as "-ing" or "-able", to the other grammatical forms. The poem's rhymes, rhythms, verbal and connotational subtleties can only be sensed in the original Portuguese version. Regarding rhymes, note for instance the original verse endings "cobertor" and "redentor", "Barão" and "varão", and so on.

O Aconchego

Estou de volta pro meu aconchego...

Aconchegadamente
aconchegável!

Aconchegando-se no aconchegante aconchego.

No aconchego do meu cobertor,

Do meu redentor,

No aconchego de um

Barão

Ou de qualquer outro "varão".

No aconchego do lar,

Permissão pra te amar. No aconchego do amor, Sinto no peito o ardor.

\section{Aconchego na nuca?} Que coisa maluca!

Aconchego no mar, Aconchego no bar, Aconchego na rua, Aconchego na lua!

$[\ldots]$

\section{O Aconchego}

I am back for my aconchego ...

Aconchegingly aconchegable!

Aconcheging oneself in aconchegy aconchego.

In the aconchego of my blanket,

Of my redeemer,

In the aconchego of a Baron,

Or of any other "man".

In the aconchego of home,

Permission to love you, In the aconchego of love, I feel in my breast the ardour.

Aconchego in the neck? What a crazy thing!

Aconchego in the sea, Aconchego in the bar, Aconchego in the street, Aconchego on the moon!

$[\ldots]$ 


\begin{tabular}{|c|c|}
\hline Eu aconchego & I aconchego \\
\hline Tu aconchagas & You aconchegas \\
\hline Ele aconchega & He aconchega. \\
\hline Ora, veja! & Check this out! \\
\hline Aconchego sabor cereja, & $\begin{array}{l}\text { Aconchego with cherry } \\
\text { flavour, }\end{array}$ \\
\hline $\begin{array}{l}\text { Sabor de menta e até pi- } \\
\text { menta! }\end{array}$ & $\begin{array}{l}\text { Flavour of mint and even } \\
\text { pepper! }\end{array}$ \\
\hline Que tal semear? & How about sowing? \\
\hline $\begin{array}{l}\text { Aconchego é o que va- } \\
\text { mos plantar! }\end{array}$ & $\begin{array}{l}\text { Aconchego is what we } \\
\text { are going to plant! }\end{array}$ \\
\hline Pegue a semente & Take the seed \\
\hline $\begin{array}{l}\text { E aconchegue com a } \\
\text { gente. }\end{array}$ & And aconchegue with us. \\
\hline Vamos, tente. & Come on, try. \\
\hline Aconchegue um parente! & Aconchega a relative! \\
\hline $\begin{array}{l}\text { Continuando a conju- } \\
\text { gação, }\end{array}$ & $\begin{array}{l}\text { Continuing the conjunc- } \\
\text { tion }\end{array}$ \\
\hline Entro em ação. & I am going into action, \\
\hline Colhendo a semente & Gathering the seed, \\
\hline Transformada em gente. & $\begin{array}{l}\text { Transformed into peo- } \\
\text { ple. }\end{array}$ \\
\hline$[\ldots]$ & {$[\ldots]$} \\
\hline
\end{tabular}

Marcello Taurino's poem animated our workshop engagement with affective relations to spaces by evoking an unexpected multiplicity of senses, relations and even practices of aconchego. It thus invited explorations into how affective relations of subjectivity and space are imagined, narrated and constituted. My intention here is not to discuss these processes so much as to investigate how a semiotic creation partakes in a series of affective dynamics. The poem assists in bringing into relief affective processes that unfold on the planes of both contents and expression, as well as through wider material planes. In agreement with Guattari's emphasis on problematic affects, however, the role of semiotic contents deserves special scrutiny - not least due to its bracketing in non-representational approaches.

\section{Affectively imbued contents and the power of evocation}

... a simple image, if it is new, will open up an entire world.

\section{G. Bachelard (1994:134)}

Gaston Bachelard's account of the "self-accomplishing" (1994:153) poetic image provides a good starting point. "The poetic image", says Bachelard, "is an emergence from lan- guage, it is always a little above the language of signification" (p. xxvii). Locating the poetic image within a morethan-signifying dimension, however, Bachelard at the same time regards it as emerging from language. A kind of "force" driving poetic creation thus seems to be at work within language itself. ${ }^{20}$ And this generative force can be seen as constitutive of poetry's generative capacities regarding subjectivities:

[The image] becomes a new being in our language, expressing us by making us what it expresses; in other words, it is at once a becoming of expression, and a becoming of our being. Here expression creates being (p. xxiii).

This perspective suggests an engagement with the expression-event quite different from Massumi's approach. As this section elaborates, much more than modulating intensities that emerge on a visceral level, a poem's verses conjure a range of intensities subsisting within the evoked images (or "contents"). Bakhtin's discussion of verbal art assists in further illuminating this process.

Using the example of Pushkin's poem Remembrance, Bakhtin suggests - not unlike Bachelard - that components like "the city's wide and silent street" or "the scroll of memory" are essentially "not visual representations, not psychic experiences in general, and not words" (1990:299). Rather, through these expressive forms particular "moments of content" (p. 300) are aesthetically shaped which thereby acquire an "emotional-volitional moment" pertaining to experiential reality in its irreducible interconnectedness (p. 299). This is also the sense in which Guattari relates semiotic contents to the problematic affects: through the evocation and relational shaping of semiotic contents, affective intensities are simultaneously conjured. The intricate ways in which these contents are relationally constellated, and the various temporalities they bring into play, justify their labelling as "rich" and "complex affects" (Guattari, 1996:160).

To gain a better understanding of the poetic shaping of affectively imbued contents, let us take a look at $O$ Aconchego. The evoked contents oscillate around two poles: the prevalent connotations of the word aconchego and the singular images of this achonchego; on the one hand, the familiar aconchego of blanket and home, on the other the peculiar aconchego of the moon and the neck. Between these poles, a continuum stretches out. With Bakhtin (1981), we can characterise the first set of contents as being subject to "centripetal" forces, whereas the second set is subject to a "centrifugal" ones. Whereas the centripetal forces unify heterogeneous contents and expressions, drawing them towards semiotic norms and

\footnotetext{
${ }^{20} \mathrm{We}$ don't need to follow Bachelard, however, when he frames this force in terms of the "eternal values" of the human imagination (see Hutta, 2015).
} 
standards, the centrifugal forces singularise them, as in Guattari's notion of polysemiosis.

The ways in which contents are constellated in the midst of centripetal and centrifugal forces generates interesting effects/affects. For instance, "my blanket" evokes an image of bodily, perhaps homely snugness reminiscent of Winnicott's (1971) "transitional objects"; whereas "my redeemer" evokes relief from hardship as well as religious sentiment and perhaps also a more public kind of aconchego, since Redentor is also the name of the Christ statue on Rio's Corcovado mountain. Both evocations, "meu cobertor" and "meu redentor", appear in immediate succession, feeding laterally, or forwards and backwards, into each other: does the redeemer provide bodily warmth like a blanket? Is "my" blanket as public as "my" Redentor-statue? It is through such constellations that complex contents are poetically shaped, implicating and constantly reworking rich affects. The sensory expressive dimension sustains this evocative process, for instance through the epistrophic rhymes of "meu cobertor" and "meu redentor". I will return to this issue.

Centripetal and centrifugal forces operate not only at the level of individual words, however, but chiefly through the broader semiotic regimes that words, expressions and verses actualise. For instance, the verses "In the aconchego of home" or "In the aconchego of love" tap into centripetal metonymic chains that are ambivalent especially for people who have experienced homophobic violence: "redeemer" $\rightarrow$ guilt, shame ...; "home" $\rightarrow$ family, parents ...; "love" $\rightarrow$ intimacy, kissing ... These notions however also polysemically evoke heterogeneous memories and, moreover, they are constellated with centrifugal verses that have quite different resonances. ${ }^{21}$ Barão" and "varão", 22 enunciated by a male speaker, evoke rather queer contents, deterritorialising the ensembles evoked so far. Other verses - "aconchego in the neck" or with "flavour of pepper" - inject intense singularities that evade prevalent fields of meaning altogether. With Bakhtin, the latter (centrifugal) semiotic move can be characterised as a "defamiliarization" that destroys a word's "habitual place in a semantic series" (1990:307; see also Guattari, 1996:198). This is akin to Guattari's understanding of heterogenesis, which he frames in terms of singularising processes that are productive of new formations of subjectivity (1996; p. 159). This also fleshes out Bachelard's above-quoted assertion that "expression creates being".

\footnotetext{
${ }^{21}$ This resonates with Bakhtin's point that "the centripetal forces of the life of language, embodied in a unitary language operate in the midst of heteroglossia. [...] Alongside the centripetal forces, the centrifugal forces of language carry on their uninterrupted work" (1981:271-2).

${ }^{22}$ While the Portuguese standard word for "man" is "homen", "varão" has additional connotations of brave virility as well as respectability.
}

Poetic language, then, evokes and constellates affectively imbued contents (contents that affects subsist within). As the words and verses actualise these contents by means of centripetal and centrifugal semiotic forces, they conjure complex problematic affects. These affects are "problematic" in that they rework what Guattari (1996) calls subjects' "existential territories" - for instance a moral order, an economy of desire or a political positioning. Thus reworking subjectivities, this process of affective semiosis can have normalising as well as singularising effects. Focusing on the former, Sara Ahmed (2004), for instance, discusses how the use of the word "landmines" in a Christian Aid letter is assumed to evoke histories of pain and suffering, while concealing a wider social context of war (2004:20). "Landmines" can be seen here as intended to actualise a western-centric semiotic of charity (p. 21), "triggering" in Guattari's above-quoted words "a complex feeling of repulsion, revolt, and compassion". But apart from affectively actualising hegemonic semiotics, especially creative formats like poetry also bear the potential to instigate processes of heterogenesis, as the above discussion has suggested. Aino Rinhaug's (2012) discussion of Black female Brazilian activists using poetry in the process of political subject formation also provides a case in point.

Much more is thus going on in the semiotic expression of affect than signifying linearization or redundant amplification. Centripetal and centrifugal forces cannot even be mapped onto Massumi's distinction between two orders of language. While Massumi generically labels the linearizing, signifying order "semiotic", both unifying and singularizing dynamics are actually semiotic processes. Fleshing out the issue of polysemiosis, Deleuze and Guattari show that, apart from signifying ones, semiotics also comprise "counter-", "post-" and "asignifying" ones, each setting off particular de- and reterritorializing, centrifugal and centripetal logics (2003:118-38). It can moreover be analysed how semiotics translate into each other, thus generating new problematizations (see S. Hutta, 2009). Perhaps, Massumi's wholesale branding of "semiotics" as linearizing, subjectivating and capturing affect also has to do with the hitherto prevalent focus in cultural analysis on hegemonic discursive formations. Without diminishing the importance of such discursive critique, Bakhtin's notion of centrifugal forces and Guattari's focus on polysemiosis offer new routes of enquiry. ${ }^{23}$

A focus on the problematic affects conjured through poetic contents demands some further conceptual fine-tuning. In the above discussion of $O$ Aconchego, I have talked about the "evocation" of contents to address their semiotic shaping and their simultaneous conjuring of affective intensities. Linguists have commonly framed this in terms of "connotation". While the notion of connotation usefully extends the view be-

\footnotetext{
${ }^{23}$ Bakhtin's and Guattari's approaches also exceed notions like différance (Dérrida) or performativity (Butler), which address the excess or failure of norms without engaging the heterogeneous in positive terms (cf. Massey, 2005:51).
} 
yond a statement's literal denotation, it has commonly been regarded as another kind of meaning associated with a statement, such as a positive or negative value judgement. At best, such meanings have also been said to include the positive or negative "affective charge" of statements, although this has rarely been taken any further (Besnier, 1990). In social research, on the other hand, "evocation" has for the most part been used intuitively, rather than being conceptually elaborated. Tuan, for instance, in his discussion of the creative capacities of language in making place, highlights that "to the Chinese artist, calligraphy, poetry, and painting are all part of one venture, the purpose of which is to evoke - or, to put it more strongly, to conjure or create - the personality and mood of a landscape" (1991:691). Note, how the "purpose to evoke" a landscape's mood is associated here with the "creation" of that mood. Just how such evocation/creation happens is unclear, as Tuan himself suggests when he mentions "the as yet little understood process by which words, grammar, semantics and syntax can evoke place" (p. 695).

My approach to evocation is akin to the notion of "poder evocador", or "evocative power", as it appears in the work of anthropologist Teresa del Valle (e.g. del Valle, 1999). Not unlike a poetic work, situations and actions, persons and symbols for del Valle evoke affectively intense conjunctures of space and time. Evocation is marked here by eliciting these contents in their experiential interconnectedness - akin to Bakhtin's depiction of affectively imbued poetic contents. ${ }^{24}$ In del Valle's discussion of ritualistic symbolisms, evocation serves to actualise powerful semiotic regimes pertaining to the gendered framing of human-nature relations. But, resonating with the notion of polysemiosis, del Valle also identifies evocations that open up new political spaces for contesting gendered norms. The notion of evocation can thus serve as a capacious tool for tracing the affective-semiotic dynamics unfolding through poetic language and a range of further expressions.

Rather than originating in stimuli impinging on the physical body, then, affective intensities conjure and work semiotic contents as part of dynamic and heterogeneous semiotic regimes. A further conceptual readjustment is in order here. For what actually drives centripetal and centrifugal dynamics is their expressive enactment, the actual enunciation, or "utterance" in linguistic expressions: "Every concrete utterance of a speaking subject serves as a point where centrifugal as well as centripetal forces are brought to bear", says Bakhtin (1981:272). Such "tension-ridden" (ibid.) dynamism, we could add, is at work where a poem is recited and listened to, as well as where it is created. It is thus the dynamism set off in the process of expressive actualisation that shapes contents in the midst of heterogenous semiotic forces. This dynamism is itself affective, which leads back to

\footnotetext{
${ }^{24}$ This experiential interconnectedness might be usefully framed in terms of Henri Bergson's concept of "duration" (see Middleton and Brown, 2005:57-83).
}

the issue of affective "tendencies" animating speech. Where so far I have treated $O$ Aconchego as a written piece of text, I will now consider it as a concrete expressive enactment pertaining to both its creation and its recital in the workshop. Such a perspective also casts into stronger relief the role $e x$ pression plays in the affective life of semiotics.

\section{Prosody, or, the affectivity of expression}

... in the art of pronunciation, [...] it is music which enters the language and rediscovers there what is musical, what is 'amorous'.

\section{R. Barthes (1991:283)}

"In verbal artistic creation", Bakhtin notes, "it is particularly evident that the aesthetic object has the character of an event" (1990:317). This eventful character, he argues, ensues from the very "feeling of verbal activeness", the feeling "of a movement", which is poetry's "governing moment" (p. 309). Such a feeling of a movement also animated the creation of $O$ Aconchego. As Marcello Taurino explains after reciting the poem in the workshop, he started to write while riding on the bus, which is often "when the words start coming". The first words that came to his mind was the song line "Estou de volta pro meu aconchego ...", which inspired further and further verses, thus initiating an evocative-expressive process. It is in this sense that Bakhtin, according to Guattari, "in no way turns affect into the passive correlative of enunciation, but into its engine" (p. 159). Affect is thus a latent tendency - a "dis-position of enunciation", as Guattari (p. 160) puts it. It is expressed, however, not despite semiotics, but in taking semiotic enunciation as its positive condition of effectivity. Affects, in other words, are not just circumstantially associated with contents and expressions; they rather subsist within them. While they are conjured along with evoked contents, they simultaneously drive the relational constitution of these contents.

What is particularly significant regarding this affective process of enunciation is that, as Bakhtin further specifies, it encompasses ethical evaluations, verbal connections, significations and the sound of words generated, all at once. To become effectively affective, a poetic creation necessarily works all of language's components, which relates back to Bakhtin's point that "poetry needs language in its entirety"; in the process of enunciation, it "squeezes all the juices from language" (Bakhtin, 1990:310). Thus involving all the facets of content and expression simultaneously, it taps the affective intensities subsisting within all of them. This is precisely what elicits the intense feeling of a movement, signalling, as Guattari puts it, "an ultimate level of verbal affect": "An affect speaks to me, or at the very least it speaks through me" (1996:160).

In this process, the plane of expression figures prominently. Where contents conjure problematic affects, expres- 
sion persistently actualises sensory affects that conjoin with them. Among the various expressive substances processed, one is particularly striking: prosody. Deriving from ancient Greek $\pi \rho \circ \sigma \omega \delta i \alpha$, "song sung to music", prosody concerns the manner of speaking, the nuancing and colouring through features like intonation, rhythm, stress, speed or volume in speech. Another neglected phenomenon in linguistic and social research (Wennerstrom, 2001:4-6), prosody varies expressions in virtually infinite ways, as features like pitch, tempo or volume are contingently modified and combined. ${ }^{25}$

Most obviously, prosody in this process modifies contents through altering a statement's meaning (or, more specifically, its locutionary performance and illocutionary force). Pronounce "It is cold" in three different ways. Ten people performing the experiment will likely generate 30 subtle variations of meanings that might range from "this is a silly exercise" to "it actually is darn cold!". Linguists and anthropologists have tended to limit the effects of prosody to such a function of signification, scrutinising the infinite ways in which prosody affirms, twists or reveals meaning (Wennerstrom, 2001). Now, consider the different affects actualised as you vary your pronunciations of "It is cold". Along with its different meanings, the semiotic contents evoked each time also effectively elicit different variations of affect - say from boredom to a sense of misery. Just as evocation is not just connotation that signifies, prosody is more than another means of denotation or connotation. ${ }^{26}$

Consider the verses "Aconchego na rua, Aconchego na lua!'. Moving from the already curious association of aconchego and street to an outright surprising "aconchego on the moon!", Marcello Taurino's voice, as can be heard on the recording, simultaneously heightens pitch and slows down to lend expressive form to this spatial oddity: "na $\uparrow l u \uparrow::: a \downarrow$ " (to use a simple and intuitive transcription). Throughout the poem, evocation is sustained by such a prosodic line of expression. The content-substance evoked here has to do with the peculiarity of "the moon" as a place of aconchego, rather than, say, with romantically indulging in the thought of escaping to the moon, which could be conveyed through different prosody (e.g. "na $\uparrow l u \downarrow: a \downarrow ")$. More than simply sending out the message that "this is strange", however, the prosodic shape expresses a content imbued with a feeling of strangeness; it is generative of the very intensity of aconchego conjured as part of this odd content. It is through this prosodic shaping, in other words, that the content of

\footnotetext{
${ }^{25}$ This variability of prosody in speech is in contrast to the much more limited range of variation in syntax, lexicon or what linguists call "segmental" phonology.

${ }^{26}$ While affect has made sporadic appearances in the linguistic literature on prosody, it has again been commonly conceived of as a kind of message delivered, for instance in terms of what William Labov (1972) calls the "evaluative devices" in story-telling (see Besnier, 1990:430; Wennerstrom, 2001:204). For a notable exception, see Kehrein (2002).
}

“Aconchego na lua!' becomes affectively intense, effectively performing the semiotic effect of defamiliarization addressed above.

Prosody, then, is paradigmatic of the affectivity expressions gain in the process of their enunciation. Their unfolding, eventful forming through rhythm, pitch, speed, and so on evokes affectively imbued content-substances, effecting their participation in centripetal and centrifugal semiotics. Expressions are also affective, however, in another, more immediate way. A shrill voice may hurt the ears without even evoking a particular content. Likewise, note how $O$ Aconchego starts out with the purely verbal, sonic and rhythmic expressions introduced through the redundancies "Aconchegadamente aconchegável" and "Aconchegando-se no aconchegante aconchego". The sensory intensities springing from the words' rhythms and aconchegy sounds (along with the rather nonsensical contents evoked by their redundant formulations) are generative of the poem's very movement or verbal affect. It is also conspicuous that the first words that "started coming" to Marcello Taurino's mind where part of a piece of music. The song line, "Estou de volta pro meu aconchego..." introduces a particular rhythmicity, as well as a melodic line, sound and voice. These features are vital in summoning the virtual, as yet unformed "disposition of enunciation", or "proto-enunciation", as Guattari $(1996: 160)$ also calls it. ${ }^{27}$

Thus, the affectivity springing from expressive forms and substances deserves special attention. At this point it is useful, however, to return to Guattari's suggestion that problematic, content-related affects are "at the basis of sensory affects". More specifically, it seems worth examining the concrete ways in which affects conjured through contents and affects conjured through expressions intersect or conjoin. Such an approach also enables a better understanding of how semiotics partake in relations of affecting and being affected.

\section{Refrain, voice and the material-semiotic}

But strictly orality is at the intersection. It speaks with its mouth full. It is full of inside and full of outside.

\section{F. Guattari (1995:89)}

In their famous chapter "Of the Refrain" in A Thousand Plateaus, Deleuze and Guattari (2003) have developed an entire ontology of how human and non-human creativity

\footnotetext{
${ }^{27}$ Such prominence of musical expression might not be by coincidence in view of the privileged role that has been attributed to "the internal music of the composing process" (Baker, 1986:20) in poetry (see also Perloff and Dworkin, 2009b). Some authors have even insisted that what "comes first" is "a certain musical mood" (Nietzsche/Schiller) or "rhythm" (Valéry) (see Baker, 1986:20; Hallberg, 2008:143)
} 
emerges from affective expressivity. ${ }^{28}$ The repetition and variation of expressive components, or refrains, in bird songs as well as in paintings or pieces of music, they argue, constitutes affectively intense "territories". Various authors have subsequently discussed the "refrain-ing" of heterogeneous sounds, images, gestures or movements into affective territories that can be subjective and collective, powerful and transformative. Chisholm (2014), for instance, delineates de- and reterritorializing spatial imaginations through verbal repetitions in poetry; McCormack (2013) traces the generation of new experiences through the rhythmic patterning of dance (and other) movements; and Bertelsen and Murphie (2010) describe the emergence of new fields of expression as well as political formations through visual refrains circulating through public media (see also Wise, 2000). Several authors moreover indicate how sonic, visual or gestural expressions align or converge with each other.

Writings on the refrain tackle the subjective and spatial effects of affectively intense expressions. Deleuze and Guattari's "Of the Refrain" is explicit and consistent about this focus. ${ }^{29}$ This focus bears the double risk, though, of eclipsing the question of contents and of (erroneously) conceiving refrains as not semiotic at all, reintroducing the semiotics-ascapture axiom. ${ }^{30}$ Guattari, by contrast, pays direct attention to the role of contents. For him, while refrains unfold through the plane of expression, they simultaneously occupy an "intersectional position [...] between the sensory and the problematic dimensions of enunciation" (1996:162). As an example from Marcello Taurino's poem, consider the anaphoric repetition of "No aconchego" and "Aconchego no/na" across several verses. On the expressive plane, these refrains follow on from the verbal redundancies of "Aconchegadamente aconchegável" and so on, continuing the conjuring and variation of the sonorous and rhythmic intensities of the words. On the plane of contents, meanwhile, they take part in the on-going evocation of affectively imbued aconchego images. Sensory levels come into play, then, as they are folded into the rich affective dynamism of content-related problematization. It is in this sense that I have also traced the affectivity of prosody as it interrelates with the contents invoked as part of an unfolding affective movement.

\footnotetext{
${ }^{28}$ Guattari first developed the notion of the refrain, or "ritornello" in The Machinic Unconscious. It was then further elaborated in Deleuze and Guattari (2003), which is the reference of most discussions.

${ }^{29}$ Even where they discuss complex artistic formations, they focus on those that develop precisely by circulating around expression - such as European Romanticism where "matter ceased to be a matter of content, becoming instead a matter of expression" (Deleuze and Guattari, 2003:340).

${ }^{30}$ Bertelsen and Murphie, for instance, while implicitly addressing a whole range of semiotic contents, situate their approach in the context of Massumi's interest in how intensities "move each other, and transform and translate under or beyond meaning, semantics, fixed systems, cognitions" (2010:147).
}

The question of how affectivity unfolds through the plane of expression also relates to broader issues regarding the relation between the semiotic and the material. For instance, recent discussions have considered how social encounters are mediated by voices and how the "sonorous" features of speech constitute atmospheres (see Bissell, 2015:152; Kanngieser, 2011). The voice can in fact be seen as paradigmatic of the conjuncture of semiotic and non-semiotic materiality. Consider how the breath viscerally sustains life as much as its touching the vocal chords enables speech, and how the mouth serves both physical nutrition and the voice (cf. Deleuze, 1990; Guattari, 1995). It is especially in verbal art, Bakhtin thus points out, that the subject gets bodily deeply involved, since the expressive sound is generated from within the organism (1990:314). In a similar vein, Rinhaug argues that poetry's capacity of "corporeal semiosis" (2012:175) has proved vital in Afro-Brazilian identity and subjectivity formation, as it has enabled activists to reclaim a (Black) body through orality.

As the movement of expression works such features as prosody, not only are the semiotic realms of evocation and expression actualised, but so are also those parts of the speaker's very body sustaining the expressive function. Marcello Taurino's intonation of "na $\uparrow l u \uparrow::: a \downarrow$ ", so we must assume, involves distinctive contractions of the vocal chords. Expression is dynamically folded back into physical materiality here. Habitus (e.g. a style of speaking) forms a mediating role in this process of embodiment. But the point here is that the voice actualises capacities to affect and to be affected simultaneously on expressive and organic as well as wider material levels. This is also why a high-pitched voice can express odd contents or make glass break. On the other hand, this conjuncture entails a permanent possibility of expressive and vital functions re-collapsing ("Did you just laugh or cough?"). This way, semiotic expression and materiality constantly intervene into each other as part of an expressive movement. The affectivity of this movement, then, its felt verbal affect, traverses not only semiotic contents and expressions, but also further materialities.

\section{Conclusion: some implications for social research}

Semiotics play a vital role in affective dynamism. While non-representational discussions have called attention to the affective forces subsisting in speech as well as the becoming-affective of expressions, they have gravitated around verticalist conceptions, viewing semiotics as capture. In particular, they have also tended to bracket affectively imbued contents altogether. As a corrective, the paper has suggested some pathways for investigating the expression of affect and the affectivity of expressions, conceived as two aspects of an unfolding affective-expressive process. ${ }^{31}$

\footnotetext{
${ }^{31} \mathrm{My}$ focus on such an unfolding process resonates with Wetherell's argument in favour of a processual understanding of the
} 
It has thus sought to further the discussion around how to conceive the relation between semiotics and affect (to "code"/"translate"/"construct"/"amplify"/"modulate"...?).

Affects, I have argued, "subsist" as virtual tendencies within semiotic contents and expressions. These virtual tendencies are actualised in concrete expressive enactments, thus conjuring problematic and sensory affects. Affect can consequentially be viewed as simultaneously driving expression and emerging from it; as virtual affects are expressed ("expression of affect"), expressions become affective ("affectivity of expression").

Regarding the mentioned non-representational discussions, there seems to be a need in particular to specify the semiotic dynamics that are at work in the context of verbal commentary (e.g. Bissell, 2014; McCormack, 2013), the interaction with media (e.g. Angel and Gibbs, 2006; Hansen, 2004), or the encounter with shadows (Massumi, 2002a). While all semiotics can be said to involve a moment of "capture" in that as yet unformed matters become semiotically formed (Hjelmslev, 1961:57), this notion of capture obscures the actual heterogeneity of semiotic processes, reductively pitting semiotic reterritorialization against affective dynamism. Discursive and semiotic methodologies, on the other hand, might derive new inspiration from considering the singularising dynamics of defamiliarization or heterogenesis that are at work as prevalent semiotic regimes are deterritorialised through affectively intense contents. "[A] simple image, if it is new, will open up an entire world", as Bachelard (1994:134) notes. ${ }^{32}$ Such analyses, however, also have to deal with thorny methodological questions around how to account for affective intensities that are often ephemeral. Traversing academic disciplines is certainly in order here - not only by turning to the sciences, as affect theorists have frequently done. Discussions in linguistics and literature have for instance developed succinct methods to analyse and transcribe live poetry as well as a range of prosodic features (e.g. Kehrein, 2002; Novak, 2011).

My discussion also prompts a reconsideration of processes of affecting and being affected. Frequently, these processes have been framed in terms of "affective transmission", assuming the direct circulation of visceral affect, or even physical substances body to body (e.g. Brennan, 2004; for a critical discussion see Wetherell, 2012:140-148). Instead, appreciating unfolding affective-expressive movements highlights that when bodies affect one another, they enact semiotic planes of both contents and expressions, along with the material ensembles they are situated in. It could thus be scrutinised how other workshop participants are affectively drawn into the unfolding semiotic process as Marcello Taurino recites his poem. Apart from the prosodic expressivity, evoked

\footnotetext{
"affective-discursive", in particular in her (2012:67-74) discussion of William Reddy's approach.

${ }^{32}$ Roland Barthes' (1991) discussion of the "punctum" also comes to mind (see Brinkema, 2014:78-110).
}

contents and vocal materiality, the facial expressions of participants, the group dynamics or the atmosphere in the room all come into play. What centripetal or centrifugal dynamics might this unfolding event feed on? And how are these dynamics part of an always already "dialogic" process (see Wetherell, 2012:74)?

Hjelmslev's open-ended conception seems particularly suitable for thus investigating how affects unfold through and across different expressive substances, including for instance poems, faces or furniture. How do the semiotic movements differ across a digital message peppered with emoticons, a vocally and prosodically conveyed phone call, or a handwritten letter? Different substances and media of expression can be viewed here as possessing different capacities for conjuring affectively imbued contents as well as for mobilising sensory intensities, which then feed into the unfolding expressive movement. As in my paradigmatic cases of prosody and voice, this entails analytical attentiveness to such embodied and technological dimensions as facial expression or smart phone screens. What kinds of affectively imbued contents might a changing face conjure ${ }^{33}$ Corresponding to Guattari's notion of "verbal affect", we could thus trace facial, scriptural or digital kinds of affect engendered by the "feeling" of the respective expressive movements they form part of.

These questions could also give a new spin to arguments around the composite, "psychobiological" nature of the emotions (see Wetherell, 2012:61-62). And they enable new angles on the both affective and expressive constitution of spaces, an issue that has been implicitly present throughout the paper. To be sure the affective life of semiotics can be investigated not only at the micro-scale that has been the empirical focus of this paper; it could be taken to a whole range of scales.

Acknowledgements. I would like to thank Marcello Taurino for his inspiring poem $O$ Aconchego. I am also indebted to Benno Gammerl, Matthew Hannah, the anonymous reviewers and the editors for their insightful comments on earlier drafts of the article.

Edited by: B. Korf

Reviewed by: three anonymous referees

\footnotetext{
${ }^{33}$ Where affect theorists - spellbound by the spectre of visceral autonomy - have invoked evolutionary approaches to facial expression (see Leys, 2011), my understanding is closer to German psychologist Philipp Lersch's (1951). What is "of prime importance" for him to understand expression in this context, is that "the entire psychic reality has the character of the event [Geschehens]" (p. 20, emphasis in the orig., my translation) into which both the sensory and the meaningful are drawn - just as the poetic movement conjoins and works expressions and contents at once.
} 


\section{References}

Ahmed, S.: The Cultural Politics of Emotion, Routledge, New York, 2014.

Anderson, B.: Encountering Affect: Capacities, Apparatuses, Conditions, Ashgate, Farnham, 2014.

Anderson, B. and Harrison, P. (Eds.): Taking-Place: NonRepresentational Theories and Geography, Ashgate, Burlington, VT, 2010.

Angel, M. and Gibbs, A.: Media, affect and the face: biomediation and the political scene, Southern Review, 38, 24-39, 2006.

Austin, J. L.: How to Do Things With Words, Clarendon Press, Oxford, 1962.

Bachelard, G.: The Poetics of Space, Beacon Press, Boston, 1994.

Baker, P.: Modern Poetic Practice: Structure and Genesis, Lang, New York, Bern, Frankfurt am Main, 1986.

Bakhtin, M. M.: The Dialogic Imagination: Four Essays, University of Texas Press, Austin, 1981.

Bakhtin, M. M.: Supplement: the problem of content, material, and form in verbal art, in: Art and Answerability: Early Philosophical Essays, edited by: Bakhtin, M. M., Holquist, M., and Liapunov, V., University of Texas Press, Austin, Texas, 257-325, 1990.

Barnett, C.: Political affects in public space: normative blind-spots in non-representational ontologies, T. I. Brit. Geogr., 186-200, 2008.

Barthes, R.: The Responsibility of Forms: Critical Essays on Music, Art, and Representation, University of California Press, Berkeley, Los Angeles, 1991.

Bauman, R. and Briggs, C. L.: Poetics and performance as critical perspectives on language and social life, Annu. Rev. Anthropol., 19, 59-88, 1990.

Bertelsen, L. and Murphie, A.: An ethics of everyday infinities and powers: Félix Guattari on affect and the refrain, in: The Affect Theory Reader, edited by: Gregg, M. and Seigworth, G. J., Duke Univ. Press, Durham, NC, 138-157, 2010.

Besnier, N.: Language and affect, Ann. Rev. Anthropol., 19, 419451, 1990.

Bissell, D.: How environments speak: everyday mobilities, impersonal speech and the geographies of commentary, Soc. Cult. Geogr., 16, 146-164, doi:10.1080/14649365.2014.958520, 2015.

Bondi, L.: Making connections and thinking through emotions: between geography and psychotherapy, Trans. Inst. Br. Geogr., 30, 433-448, 2005.

Boundas, C. V.: Virtual/virtuality: The Deleuze Dictionary, edited by: Parr, A., New York, Columbia University Press, 296-298, 2005.

Brennan, T.: The Transmission of Affect, Cornell University Press, Ithaca, NY, 2004.

Brickell, K.: Towards geographies of speech: proverbial utterances of home in contemporary Vietnam, T. I. Brit. Geogr., 38, $207-$ 220, doi:10.1111/j.1475-5661.2012.00503.x, 2013.

Brinkema, E.: The Forms of the Affects, Duke University Press, Durham, 2014.

Cavell, S.: Philosophy the Day After Tomorrow, Belknap Press, Cambridge, Mass, 2005.

Chisholm, D.: Juliana Spahr's ecopoetics: ecologies and politics of the refrain, Contemp. Literature, 55, 118-147, 2014.

Connolly, W. E.: Neuropolitics: Thinking, Culture, Speed, University of Minnesota Press, Minneapolis, MN, 2002.
Crouch, D.: Spatialities and the feeling of doing, Soc. Cult. Geogr., 2, 61-75, doi:10.1080/14649360020028276, 2001.

del Valle, T.: Procesos de la memoria: cronotopos genéricos, La Ventana, 9, 7-43, 1999.

Deleuze, G.: The Logic of Sense, The Athlone Press, London, 1990.

Deleuze, G.: Foucault, Athlone Press, London, 1999.

Deleuze, G. and Guattari, F.: A Thousand Plateaus: Capitalism and Schizophrenia, Continuum, London, 2003.

Dewsbury, J.-D.: Inscribing thoughts: the animation of an adventure, Cult. Geogr., 21, 147-152, doi:10.1177/1474474012469005, 2014.

Eco, U.: Semiotics and the Philosophy of Language, Indiana University Press, Bloomington, 1984.

Genosko, G.: Guattari's schizoanalytic semiotics: mixing Hjelmslev and Peirce, in: Deleuze \& Guattari: New Mappings in Politics, Philosophy, and Culture, edited by: Kaufman, E. and Heller, K. J., University of Minnesota Press, Minneapolis, 175-190, 1998.

Gould, D. B.: Moving Politics: Emotion and ACT UP's Fight Against AIDS, University of Chicago Press, Chicago, 2009.

Guattari, F.: Machinic orality and virtual ecology, in: Chaosmosis: an Ethico-Aesthetic Paradigm, Indiana University Press, Bloomington, Indianapolis, 88-97, 1995.

Guattari, F.: Ritornellos and existential affects, in: The Guattari Reader, edited by: Guattari, F. and Genosko, G., Blackwell Publishers, Oxford, OX, UK, Cambridge, Mass., 158-171, 1996.

Guattari, F. and Rolnik, S.: Molecular Revolution in Brazil, Semiotext(e), Los Angeles, 2008.

Hallberg, R. von: Lyric Powers, University of Chicago Press, Chicago, 2008.

Hansen, M.: New Philosophy for New Media, MIT Press, 2004.

Heidegger, M.: Poetry, Language, Thought, Perennial, New York, 2001.

Hemmings, C.: Affective solidarity: Feminist reflexivity and political transformation, Feminist Theory, 13, 147-161, doi:10.1177/1464700112442643, 2012.

Hjelmslev, L.: Prolegomena to a Theory of Language, The University of Wisconsin Press, Madison, WI, 1961.

Hutta, J. S.: Geographies of Geborgenheit: beyond feelings of safety and the fear of crime, Environ. Plann. D, 27, 251-273, doi:10.1068/d3308, 2009.

Hutta, J. S.: Queer geographies of geborgenheit: The LGBT politics of security and formations of agency in Brazil, PhD Thesis, Faculty of Social Science, The Open University, Milton Keynes, 2010.

Hutta, J. S.: Andere Geborgenheiten: Topophilie jenseits des Authentizitätsdiskurses, sub/urban, 3, 109-124, available at: http: //nbn-resolving.de/urn:nbn:de:101:1-20150921898, 2015.

Hutta, S.: Translation in excess: Engaging semiotics and the untranslatable, GJSS, 6, 40-62, 2009.

Kanngieser, A.: A sonic geography of voice: Towards an affective politics, Prog. Hum. Geog., 36, 336-353, doi:10.1177/0309132511423969, 2011.

Katz, J.: How Emotions Work, University of Chicago Press, Chicago, IL, 1999.

Kehrein, R.: Prosodie und Emotionen, De Gruyter, 2002.

Kleres, J.: Emotions and narrative analysis: A methodological approach, J. Theor. Soc. Behav., 41, 182-202, doi:10.1111/j.14685914.2010.00451.x, 2011. 
Konstantinidou, M.: Sprache und Gefühl: semiotische und andere Aspekte, Buske, Hamburg, 1997.

Korf, B.: Neuro-Kulturgeographie, Geogr. Z., 146-163, 2012.

Labov, W.: Language in the Inner City: Studies in the Black English Vernacular, Univ. of Pennsylvania Press, Philadelphia, 1972.

Latham, A.: Research, performance, and doing human geography: some reflections on the diary-photograph, diary-interview method, Environ. Plann. A, 35, 1993-2017, doi:10.1068/a3587, 2003.

Laurier, E.: Representation and everyday use: how to feel things with words, in: Taking-Place: Non-Representational Theories and Geography, edited by: Anderson, B. and Harrison, P., Ashgate, Burlington, VT, 131-146, 2010.

Lersch, P.: Gesicht und Seele: Grundlinien einer mimischen Diagnostik, Ernst Reinhardt Verlag, München, Basel, 1951.

Leys, R.: The turn to affect: a Critique, Critical Inquiry, 37, 434472, 2011

Lorimer, H.: Cultural geography: the busyness of being 'more-thanrepresentational', Prog. Hum. Geog., 1, 83-94, 2005.

Lorimer, H.: Cultural geography: worldly shapes, differently arranged, Prog. Hum. Geog., 31, 89-100, doi:10.1177/0309132507073540, 2007.

Lorimer, H.: Cultural geography: non-representational conditions and concerns, Prog. Hum. Geog., 32, 551-559, doi:10.1177/0309132507086882, 2008.

Manning, E. and Massumi, B.: Thought in the Act: Passages in the Ecology of Experience, Univ. of Minnesota Press, Minneapolis, Minn., 2014.

Massey, D. B.: For Space, SAGE, London, Thousand Oaks, Calif., 2005.

Massumi, B.: The autonomy of affect, Cultural Critique, 83, 83109, doi:10.2307/1354446, 1995.

Massumi, B.: Parables for the Virtual: Movement, Affect, Sensation, Duke University Press, Durham, NC, 2002a.

Massumi, B.: Introduction, in: A shock to thought: Expression after Deleuze and Guattari, edited by: Massumi, B., Routledge, London, New York, XIII-XXXVIII, 2002 b.

Massumi, B.: Floating the social: an electronic art of noise, Reverberations, 2012.

Mazzarella, W.: Affect: what is it good for?, in: Enchantments of Modernity: Empire, Nation, Globalization, edited by: Dube, S., Critical Asian studies, Routledge, London, 291-309, 2009.

McCormack, D. P.: An event of geographical ethics in spaces of affect, T. I. Brit. Geogr., 28, 488-507, 2003.

McCormack, D. P.: Refrains for Moving Bodies: Experience and Experiment in Affective Spaces, Duke University Press, Durham, 2013.

Middleton, D. and Brown, S. D.: The Social Psychology of Experience: Studies in Remembering and Forgetting, SAGE, London, Thousand Oaks, Calif., 2005.

Novak, J.: Live Poetry: An Integrated Approach to Poetry in Performance, Rodopi, 2011.

Papoulias, C. and Callard, F.: Biology's gift: interrogating the turn to affect, Body \& Society, 16, 29-56, doi:10.1177/1357034X09355231, 2010.
Perloff, M. G. and Dworkin, C.: Introduction: the sound of poetry / the poetry of sound, in: The Sound of Poetry, the Poetry of Sound, edited by: Perloff, M. G., Univ. of Chicago Press, Chicago, 1-17, 2009a.

Perloff, M. G. and Dworkin, C. (Ed.): The Sound of Poetry, the Poetry of Sound, Univ. of Chicago Press, Chicago, 2009b.

Riley, D.: Impersonal Passion: Language as Affect, Duke University Press, Durham, 2005.

Rinhaug, A.: Embodied voices: embedding contemporary Afro-Brazilian women writers, African and Black Diaspora: An International Journal, 5, 163-178, doi:10.1080/17528631.2012.695219, 2012.

Schregel, S.: Raum-Macht-Beziehungen und wie man sie erforschen kann: Erfahrungen aus einem Projekt über den "Atomkrieg vor der Wohnungstür", in: Die Ordnung der Räume: Geographische Forschung im Anschluss an Michel Foucault, edited by: Füller, H. and Michel, B., Westfälisches Dampfboot, Münster, 263-272, 2012.

Seigworth, G. J. and Gregg, M.: An inventory of shimmers, in: The Affect Theory Reader, edited by: Gregg, M. and Seigworth, G. J., Duke Univ. Press, Durham, NC, 1-28, 2010.

Sharp, J.: Geography and gender: what belongs to feminist geography? Emotion, power and change, Prog. Hum. Geog., 33, 74-80, doi:10.1177/0309132508090440, 2009.

Shouse, E.: Feeling, emotion, affect, M/C Journal, 8, w/o pages, 2005.

Thien, D.: After or beyond feeling? A consideration of affect and emotion in geography, Area, 450-454, 2005.

Thrift, N.: Afterwords, Environ. Plann. D, 18, 213-255, doi:10.1068/d214t, 2000.

Thrift, N.: Intensities of feeling, Geografiska Annaler, 57-78, 2004.

Thrift, N. and Dewsbury, J.-D.: Dead geographies - and how to make them live, Environ. Plann. D, 18, 411-432, doi:10.1068/d1804ed, 2000.

Thrift, N. J.: Spatial Formations, Sage, London, 1996.

Tuan, Y.-F.: Language and the making of place: a narrativedescriptive approach, Ann. Assoc. Am. Geogr., 81, 684-696, 1991.

Wennerstrom, A.: The Music of Everyday Speech: Prosody and Discourse Analysis, Oxford University Press, Oxford, 2001.

Wetherell, M.: Affect and Emotion: a New Social Science Understanding, Sage, Los Angeles, London, 2012.

Williams, R.: Marxism and Literature, Oxford University Press, Oxford, 1977.

Winnicott, D. W.: Playing and Reality, Penguin Books, Middlesex, England, 1971.

Wise, J. M.: Home: territoriy and identity, Cultural Studies, 14, 295-310, doi:10.1080/095023800334896, 2000.

Wrana, D. and Langer, A.: An den Rändern der Diskurse: Jenseits der Unterscheidung diskursiver und nicht-diskursiver Praktiken, FQS, 8, http://www.qualitativeresearch.net/fqs-texte/2-07/ 07-2-20-d.htm, 2007. 